\title{
Self-Management Counseling and Physical Health Status among Patients with Pulmonary TB in Bogor, Indonesia
}

\author{
Muhamad Jauhar ${ }^{1,2}$, Astuti Yuni Nursasi ${ }^{3}$, Wiwin Wiarsih ${ }^{3}$ \\ ${ }^{1}$ Post Graduate Program, Faculty of Nursing, University of Indonesia, Indonesia \\ ${ }^{2}$ Infectious Disease Research Center, Faculty of Medicine, University of Padjadjaran, Indonesia \\ ${ }^{3}$ Community Nursing Department, Faculty of Nursing, University of Indonesia, Indonesia \\ Corresponding Author: Muhammad Jauhar(muhamadjauhar90@gmail.com)
}

\begin{abstract}
Background: Patients with pulmonary TB experience physical, psychological, social, and spiritual changes, affecting their physical health status. Self-management counseling is an intervention which enhances the physical health status of patients with pulmonary TB.

Purpose: This study aimed to identify the effects of self-management counseling on physical health status in patients with pulmonary TB.

Methods: This study used a pre and post-test quasi-experimental design with a control group and took place in a hospital in Bogor. The total respondents were 60 patients who were assigned into two groups and recruited using purposive sampling. The counseling was given for four sessions in two weeks for about 60-90 minutes each session. The data were collected using the functional assessment of chronic illness therapytuberculosis (FACIT-TB) and analyzed using paired t-test and independent t-test.

Results: The result showed that the physical health status in the intervention group increased significantly $(M D=8.0, p=0.000)$ compared to the control group. However, there was no influence of self-management counseling on the improvement of physical health status $(M D=3.24, p=0.314)$.

Conclusion: Self-management counseling did not significantly increase the physical health status of pulmonary TB patients. More rigorous studies are needed to investigate the effect of self-management counseling delivered at early treatment on the improvement of physical health status. It is expected that patients can manage their TB symptoms and able to improve their physical health status.
\end{abstract}

Keywords: Outpatients; physical health status; pulmonary TB; self-management

\section{BACKGROUND}

Pulmonary tuberculosis (TB) has still become a community health problem in the worldwide although anti-TB drugs and the BCG vaccine has been prescribed. The global commitment to reducing morbidity and mortality of pulmonary TB was set in the 2015-2030 SDGs policy. The number of TB cases has been increasing every year worldwide. WHO reported that there were 10.4 million people diagnosed with pulmonary TB in 2015. Indonesia came as the second highest country with pulmonary TB cases in the world accounted for 330.910 cases of pulmonary TB (10\% of cases in the world) (Ministry of Health RI, 2016). West Java became the province with the 
highest cases in Indonesia with 59.446 cases (38\% of cases in Indonesia) (West Java Central Bureau of Statistic, 2016). Of these, 8.271 cases were found in Bogor regency, a regency with the highest cases of pulmonary TB in West Java. In 2016, there were also 2.107 cases reported in a hospital in Bogor (Bogor Health Office, 2016).

The increasing number of pulmonary TB cases is caused by many factors such as lower socioeconomic level, poor sanitation, population density, unemployment, malnutrition status, lower education level, no income or less than minimum regional wage, smoking, alcohol, and other diseases such as HIV/AIDS or diabetes mellitus. TB affects not only the patients but also their family and the government. The patients lost their working time 3-4 months during treatment; reduced monthly income to $20-30 \%$ per year, and the negative stigma from society (Ministry of Health RI, 2016). Besides, the patients perceived physical and psychological changes during treatment, especially in early treatment stage. The physical changes affected daily physical activities and health status related to the quality of life (Kim \& Youn, 2015). Furthermore, physical status was also affected by occupation, education, clinical factors, nutrition status, and smoking (Masumoto et al., 2014). This condition will influence TB patients in fighting for their illness. The families beard psychological burden, and there was a change of family health status. The state or government should be able to provide funding to run the disease control program (Ministry of Health RI, 2016).

Recently, most of the patients in the hospital are provided the health education solely by nurses. To date with the development of nursing science and practice, it is important for nurses to provide an innovative intervention which is more effective, efficient, and feasible to be conducted in all health care facilities that may improve the physical health status of TB patients. Previous studies reported that self-management intervention could reduce the physical complaints and increase physical activity in patients with chronic disease (Lorig, Ritter, Pifer, \& Werner, 2014; Kim \& Youn, 2015). The form of selfmanagement interventions which can be applied is self-management counseling. However, there is limited evidence of self-management in the form of counseling to increase physical health status among patients with pulmonary TB in Indonesia. Therefore, this study is important to investigate the effects of self-management counseling on the physical health status of patients with pulmonary TB.

\section{PURPOSE}

This study aimed to identify the effects of self-management counseling on physical health status in pulmonary TB patients.

\section{METHODS}

This study used a pre-test and post-test quasi-experimental design with the control group. The respondents were pulmonary TB outpatients in a hospital in Bogor, who were assigned to the intervention and control group based on their medical check-up schedule and home addresses. The sampling technique was purposive sampling with the inclusion criteria: (1) early treatment phase (1-2 months); (2) TB confirmed by clinical and or sputum smear (+); (3) aged 18-60 years old; (4) primary education level; (5) able to read and write; and (6) able to communicate in Bahasa Indonesia. The number of the sample had been calculated by a hypothesis test using two paired population formula 
plus the possibility of drop-out and resulted in 32 patients for each group. In the end, the number of respondents in the intervention group was 30 patients. As many as 37 patients were allocated in the control group, but seven patients were lost to follow up, so only 30 respondents were included in the analysis.

Data collection was performed using Functional Assessment of Chronic Illness Therapy-Tuberculosis (FACIT-TB) instrument that had been developed by Abdulelah et al. (2015) with validity score of $0.376-0.737$ and reliability score of 0.787 . This questionnaire was filled in by respondents at the beginning and the end of the intervention. The intervention was self-management counseling that was given in four sessions within two weeks for about 60-90 minutes each session. The topic consisted of disease introduction, psychosocial and symptom management, nutrition and treatment management, and communication skills. The intervention began with the feedback and ended with a daily activity plan facilitated by facilitators.

The univariate and bivariate analyses were applied. The univariate data were presented in frequency and percentage for categorical data, mean and SD for numerical data. The normality test used Kolmogorov-Smirnov while the homogeneity test used the chisquare test. Paired t-test and independent t-test were used as the bivariate analysis (Dharma, 2011). This study had received approval from the Ethics Committee of Faculty of Nursing University of Indonesia (No. 135/UN2.F12.D/HKP.02.04/2017).

\section{RESULTS}

\section{Demographic characteristics}

Table 1 provides information about the characteristics of TB patients. About $73.3 \%$ of respondents in the intervention group and 70\% in control group were aged 18-40 years. The majority of TB patients were female, $63.3 \%$ and $50 \%$ for the intervention group and control group respectively. Regarding marital status, $63.3 \%$ of TB patients were married in both groups. Moreover, the respondents who had a high school education level were $50 \%$ for the intervention group and $60 \%$ for the control group. Most of the TB patients were unemployed accounted for $73.3 \%$ (intervention group) and $53.3 \%$ (control group). The majority of TB patients had no monthly income as many as $70 \%$ (intervention group) and $46.7 \%$ (control group). As many as $73.3 \%$ of TB patients in the intervention group and $56.7 \%$ of TB patients in the control group were not exposed to cigarettes.

Table 1. Characteristics of respondents $(n=60)$

\begin{tabular}{lrrrr}
\hline \multirow{2}{*}{ Characteristics } & \multicolumn{2}{c}{ Intervention } & \multicolumn{2}{c}{ Control } \\
\cline { 2 - 5 } & $\mathrm{f}$ & $\%$ & $\mathrm{f}$ & $\%$ \\
\hline Age & & & & \\
$\quad$ Young adult (18-40) & 22 & 73.3 & 21 & 70 \\
$\quad$ Middle adult (41-60) & 8 & 26.7 & 9 & 30 \\
Gender & & & & \\
$\quad$ Men & 11 & 36.7 & 15 & 50 \\
$\quad$ Women & 19 & 63.3 & 15 & 50 \\
Marital Status & & & & \\
$\quad$ Single & 9 & 30 & 6 & 20 \\
$\quad$ Married & 19 & 63.3 & 19 & 63.3 \\
\hline
\end{tabular}




\begin{tabular}{lrrcc}
\hline \multirow{2}{*}{ Characteristics } & \multicolumn{2}{c}{ Intervention } & \multicolumn{2}{c}{ Control } \\
\cline { 2 - 5 } & $\mathrm{f}$ & $\%$ & $\mathrm{f}$ & $\%$ \\
\hline$\quad$ Widow/Widower & 2 & 6.7 & 5 & 16.7 \\
Education Level & & & & \\
$\quad$ Elementary & 14 & 46.7 & 11 & 36.7 \\
$\quad$ High school & 15 & 50 & 18 & 60 \\
$\quad$ College & 1 & 3.3 & 1 & 3.3 \\
Occupation & & & & \\
$\quad$ Unemployment & 22 & 73.3 & 16 & 53.3 \\
$\quad$ Employee & 8 & 26.7 & 14 & 46.7 \\
Income & & & & \\
$\quad$ Had no income & 21 & 70 & 14 & 46.7 \\
$\quad<3.205 .441$ IDR & 6 & 20 & 14 & 46.7 \\
$\quad$ 23.205.441 IDR & 3 & 10 & 2 & 6.7 \\
Cigarette exposure & & & & \\
$\quad$ Not exposure & 22 & 73.3 & 17 & 56.7 \\
$\quad$ Exposure & 8 & 26.7 & 13 & 43.3 \\
\hline
\end{tabular}

\section{Physical health status}

Table 2 shows the means of the physical health status of TB patients in the intervention group before the intervention $(M=36.27, S D=14.35)$ and after the intervention $(M=44.27, S D=12.09)$. The mean of physical health status among TB patients in the control group before the intervention was $37.83(S D=12.07)$ and after the intervention was $41.03(S D=12.56)$. Table 3 shows that there was a significant increase on the means of the physical health status of TB patients before and after self-management counseling in the intervention group $(M D=8.0, p=0.000)$. The mean of physical health status before and after self-management counseling in the control group also increased $(M D=3.2)$, but the increase was not statistically significant $(p=0.061)$.

Table 2. The description of physical health status before and after intervention $(n=60)$

\begin{tabular}{ccccccc}
\hline Physical & \multicolumn{3}{c}{ Intervention } & \multicolumn{3}{c}{ Control } \\
\cline { 2 - 7 } Health & Mean & $S D$ & $95 \%$ CI & Mean & $S D$ & $95 \%$ CI \\
Status & & & & & & \\
\hline Pre-test & 36.27 & 14.35 & $28.91-39.62$ & 37.83 & 12.069 & $33.33-42.34$ \\
Post-test & 44.27 & 12.09 & $39.75-48.78$ & 41.03 & 12.560 & $36.34-45.72$ \\
\hline
\end{tabular}

Table 3. The difference of physical health status before and after intervention $(n=60)$

\begin{tabular}{lllll}
\hline Group & Mean & $S D$ & $M D$ & $p$ \\
\hline Intervention & & & & \\
$\quad$ Pre-test & 36.27 & 14.35 & 8.0 & 0.000 \\
$\quad$ Post-test & 44.27 & 12.09 & & \\
Control & & & & \\
$\quad$ Pre-test & 37.83 & 12.07 & 3.2 & 0.061 \\
$\quad$ Post-test & 41.03 & 12.56 & & \\
\hline
\end{tabular}

Table 4 shows the mean of the physical health status of TB patients after selfmanagement counseling. In the intervention group, the mean was 44.27 with $S D=12.09$ 
while in the control group, the mean was 41.03 with $S D=12.56$. There was no definite effect of self-management counseling on physical health status in the intervention group compared with the control group $(M D=3.24, p=0.314)$.

Table 4. The effects of self-management counseling on physical health status $(n=60)$

\begin{tabular}{lrrl}
\hline Group & Mean & \multicolumn{1}{l}{$S D$} & $p$ \\
\hline Intervention & 44.27 & 12.09 & \\
Control & 41.03 & 12.56 & 0.314 \\
Difference & 3.24 & -0.53 & \\
\hline
\end{tabular}

\section{DISCUSSION}

Based on the result of the study, the majority of TB patients were aged 18-40 years old (early adults). This is in line with the previous studies which suggested that most of the pulmonary TB patients were in the productive age. The mean of pulmonary TB patients' age was between 18-55 years old (Bauer et al., 2015; Louw, Mabaso \& Peltzer, 2016; Noorratri, Margawati \& Dwidiyanti, 2016). Based on the Bogor health profile, most of the population (50.39\%) in 2015 is in the range of 15-40 years (Bogor Health Office, 2016). It can be concluded that the number of the TB cases number in Bogor is influenced by age. The early adulthood groups are at productive age so they must work to meet daily needs. They may have greater mobility and social interaction than other age groups. It causes the early adulthood group to be at risk of TB disease from others who have been infected with TB.

The majority of TB patients were females. This result was different from a previous study which reported that the majority of pulmonary TB patients were males (Louw, Mabaso \& Peltzer, 2016). This result occurs may due to the immunity level in females is lower than males. The females usually perform routine health checks which can provide early identification of TB cases (Bauer et al., 2015). Based on WHO report in 2016, TB disease was one of the highest causes of death in females in the world in 2015. It can be concluded that females are at risk of exposure to pulmonary TB.

The majority of TB patients were married. This result is in line with the previous study which reported that majority of pulmonary TB patients are married (Atif et al., 2014; Masumoto et al., 2014; Nooratri, Margawati \& Dwidiyanti, 2016; Prasetyo, Preechawong \& Yunibhand, 2015; Rashmi, Prasad \& Chand, 2014). Most of the pulmonary TB patients are married because they were included in adulthood aged groups. Both married and unmarried patients have the same risk of exposure to TB.

A half of TB patients graduated from high school. It is in line with the previous study which reported that a half of the pulmonary TB patients had completed high school level (Louw, Mabasso \& Peltzer, 2016; Prasetyo, Preechawing \& Yunibhand, 2015). People with secondary education backgrounds find it harder to understand information about TB transmission completely. The education background of pulmonary TB patients in Bogor Regency is also affected by the level of education among the population in Bogor which is equivalent to junior and senior high school (Bogor Central Bureau of Statistic, 2016). 
The majority of TB patients were unemployed so that they had no monthly income. This finding is supported by previous studies which revealed that half of the pulmonary TB patients were not working; as a result, TB patients get income from their families during treatment (Louw, Mabasso \& Peltzer, 2016; Noorartri, Margawati \& Dwidiyanti, 2016; Prasetyo, Preechawong \& Yunibhand, 2015). Based on the report of the Ministry of Health in 2013, the prevalence of pulmonary TB tended to increase in patients who were unemployed. TB patients who are undergoing treatment decide to stop working because they have to perform routine health checks and take medication in health service facilities. Also, TB patients must adapt to the symptoms of illness and drug side effects that affect their physical health (Ministry of Health RI, 2013). Socioeconomic status is also associated with access to information and healthcare facilities. The difficulty of accessing information about pulmonary TB disease makes people less aware of the danger of the disease transmission.

Most TB patients were not exposed to cigarettes. However, some of them had cigarette exposure either as active smokers or passive smokers. Cigarettes contain nicotine and tar which can damage the mechanism of pulmonary defense against bacteria so that the risk of exposure to Mycobacterium tuberculosis increases. This is congruent with previous studies which explained that most of the pulmonary TB patients had smoking habits or second-hand smoke exposure (Atif et al., 2014; Bauer et al., 2015; Masumoto et al., 2014). Smoking behavior in the population aged more than 15 years in Indonesia increased to $36.3 \%$ in 2013, in which $25.5 \%$ of active smokers lived in rural areas, and $32.3 \%$ of smokers come from low economic levels (Ministry of Health RI, 2013). This is in accordance with the characteristics of pulmonary TB patients in Bogor.

Before the implementation of self-management counseling, the physical health status in the intervention group was lower than that in the control group. After the implementation, the physical health status in the intervention group was higher than the control group. The physical health status of pulmonary TB patients changed not only due to the impact of illness but also the anti-TB drugs side effects. The physical health status is influenced by the characteristics of the patients. Women are more susceptible to diseases because they have lower immunities, so the progress of the disease is more progressive (WHO, 2016). Low education level, cigarette exposure, BTA (+) examination results, and drug side effects were associated with low physical health status that affects the quality of life (Masumoto et al., 2014). Work is also related to physical health aspects of the quality of life of TB patients (Masumoto et al., 2014).

Based on the finding, the difference of physical health status was not significant before and after self-management counseling in the intervention and the control group. This is in accordance with a previous study by Kazawa, Takeshita, Yorioka, and Moriyama (2015) which reported that disease management programs during 12 months are unable to improve the health status of diabetic nephropathy patients. However, there were several previous studies showing different results. Lorig et al. (2014) explained that a self-management program of chronic diseases given for six weeks could reduce the physical complaints of patients with chronic mental illness. Kim and Youn (2015) also reported that a self-management program of chronic diseases could increase physical activity in patients with chronic diseases. The difference in the result of these studies 
was influenced by differences in the client characteristics, symptoms of illness and time duration of the intervention. Physiologically, pulmonary TB patients experienced a decrease in health status from the early stages of treatment (1-2 months) and gradually increased during one month of treatment and stabilized at the end of the continues stage of treatment, thus affecting the results of the study (Atif et al., 2014; Bauer et al., 2015; Jaber et al., 2016). This can be a consideration for nurses in providing self-management counseling to pulmonary $\mathrm{TB}$ patients especially regarding the intervention duration.

Self-management counseling can be given in health care facilities such as public health centers and hospitals as one of integrated discharge planning with Directly Observed Treatment Shortcourse (DOTS) program with family and community approach. The implementation of this intervention focuses on promotive, preventive, and rehabilitative efforts. Nurses should be able to identify the physical health status of pulmonary TB patients during treatment and are required to be innovative in providing interventions. Therefore, changes in physical complaints that occur due to the body's responses to diseases and side effects of treatments can be minimized. Stable physical health status is expected to ensure the completeness and success of treatment.

\section{CONCLUSION}

Based on the result of this study, it can be concluded that self-management counseling did not significantly increase the physical health status of pulmonary TB patients. This probably happens because the counseling was given in a short period of time. Therefore, it is suggested that the intervention is conducted in longer duration and various intervention. This study recommends that community health nurses be able to conduct promotive and preventive efforts to minimize the risk of treatment dropped out. Also, the hospital or public health center could develop this intervention by integrating it with DOTS program.

\section{ACKNOWLEDGMENT}

The authors would like to thank the Directorate of Research and Community Services, University Indonesia which provided funding for this study and publication, the nurses, health volunteers, community social workers, TB patients and families who participated in this study.

\section{REFERENCES}

Abdulelah, J., Sulaiman, S.A.S., Hassali, M.A., Blebil, A.Q., Awaisu, A., Bredle, J.M. (2015). Development and psychometric properties of a tuberculosis-specific multidimensional health-related quality of life measure for patients with pulmonary tuberculosis. Value in Health Regional Issues, 6, 53-59.

Atif, M., Sulaiman, S.A., Shafie, A.A., Asif, M., Sarfraz, M.K., Low, H.C., Babar, Z.U. (2014). Impact of tuberculosis treatment on health-related quality of life of pulmonary tuberculosis patients: a follow-up study. Health and Quality of Life Outcome, 14, 12-19.

Bauer, M., Ahmed, S., Benedetti, A., Greenway, C., Laili, M., Leavens, A., ... Schwartzman, K. (2015). The impact of tuberculosis on health utility: a longitudinal cohort study. Quality Life Res, 24(6), 1337-1349. 
Bogor Central Bureau of Statistic. (2016). Kabupaten Bogor dalam angka pada tahun 2016 [Bogor Regency in figure 2016]. Retrieved April 25, 2017, from http://bogorkab.bps.go.id/new/website/pdf_publikasi/Kabupaten Bogor-DalamAngka-2016.pdf

Bogor Health Office. (2016). Profil kesehatan Kabupaten Bogor pada tahun 2015 [Bogor regency health profile in 2015]. Bogor: Bogor Health Office.

Dharma, K. K. (2011). Metodologi penelitian keperawatan: panduan melaksanakan dan menerapkan hasil penelitian [Nursing research methodology: Guides in implementing and applying research results]. Jakarta: Trans Info Media.

Jaber, A.A.S., Khan, A.H., Sulaiman, S.A.S., Ahmad, N., \& Anaam, M.S. (2016). Evaluation of health-related quality of life among tuberculosis patients in two cities in Yemen. Journal PLOS One, 11(6), 1-19.

Kazawa, K., Takeshita, Y., Yorioka, N., \& Moriyama, M. (2015). Efficacy of a disease management program focused on acquisition of self-management skills in predialysis with diabetic nephropathy: 24 months follow-up. Journal of Nephrology, 28(3), 329-38.

Kim, S.H. \& Youn, C.H. (2015). Efficacy of chronic disease self-management program in older Korean adults with low and high health literacy. Asian Nursing Research, 9(1), 42-46.

Lorig, K., Ritter, P.L., Pifer, C., \& Werner, P. (2014). Effectiveness of the chronic disease self-management program for persons with a serious mental illness: a translation study. Community Mental Health Journal, 50(1), 96-103.

Louw, J.S., Mabaso, M., \& Peltzer, K. (2016). Change in health-related quality of life among pulmonary tuberculosis patients at primary health care settings in South Africa: a prospective cohort study. Journal PLOS One, 11(5), 1-13.

Masumoto, S., Yamamoto, T., Ohkado, A., Yoshimatsu, S., Querri, A.G., \& Kamiya, Y. (2014). Factors associated with health-related quality of life among pulmonary TB patients in Manila, the Philippines. Quality Life Research, 23(5), 1523-1533.

Ministry of Health RI. (2013). Penelitian kesehatan dasar 2013 [Basic health research 2013]. Retrieved on March 9, 2017, from

http://www.depkes.go.id/resources/download/general/Hasil\%20Riskesdas\%20201 3.pdf?opwvc $=1$

Ministry of Health RI. (2016). Profil kesehatan Indonesia 2015 [Indonesia Health Profile 2015]. Retrieved on February 28, 2017, from: http://www.depkes.go.id/resources/download/pusdatin/profil-kesehatanindonesia/data-dan-informasi-2015.pdf

Noorratri, E.D., Margawati, A. \& Dwidiyanti, M. (2016). The factors of self-efficacy among pulmonary TBC patients. Journal of Nursing and Health, 2(1), 24-28.

Prasetyo, Y.A., Preechawong, S. \& Yunibhand, J. (2015). Effect of a tuberculosis health promotion on medication adherence among tuberculosis patients. Journal of Health Research, 29(1), 47-53.

Rashmi., Prasad, S., \& Chand, S. (2014). Identify the impact of TBC on health status and coping strategies adopted by TBC patients. International Journal of Nursing Education, 6(1), 222-225. 
Nurse Media Journal of Nursing, 8(1), 2018, 43

West Java Central Bureau of Statistic. (2016). Provinsi Jawa Barat dalam angka 2016 [West Java Province in figure 2016]. Retrieved on February 28, 2017, from http://jabar.bps.go.id/new/website/pdf_publikasi/Jawa-Barat-Dalam-Angka2014.pdf

World Health Organization (2016). Tuberculosis in women. Retrieved on February 28, 2018, from http://www.who.int/tb/publications/tb_women_factsheet_251013.pdf 